\title{
BETTER LIVING THROUGH POLICE DISCRETION
}

\author{
Harold E. Pepinsky*
}

I

\section{INTRODUCTION}

Commentaries have generally overlooked the following properties of police discretion: 1) it is required by accountability; 2) it consists of unexplained variation in police decisions; 3 ) it does not contribute to the overwhelming class bias in policing; 4) it is increased by the imposition of laws, regulations, and rules; and 5) its creation is necessary for reducing the injustice of policing.

Accountability requires discretion. If society aims to use regulation to make the pólice accountable to the citizens they serve, society's rules must not only channel accountability, but must create discretion. And if society aims to reduce the level of class bias in law enforcement through accountability, discretionary rules must be designed to offer an incentive for the police to engage in aggressive nonenforcement.

These premises for guiding police discretion run counter to Davis's. ${ }^{1}$ Davis's work is the foundation for much of the contemporary writing on discretion, especially in legal forums such as Law and Contemporary Problems. ${ }^{2}$ While Davis is to be praised for focusing scholarly attention on problems of police accountability and discretion, his premises severely restrict our capacity to formulate ways to solve those problems.

This article begins from the premise that discretion is a desirable part of policing. It proposes a system of accountability designed to generate discretion in a way that reduces the injustice of selective law enforcement.

II

\section{ACCOUNTABILITy Requires Discretion}

The proposition that accountability requires discretion requires no empirical demonstration; it can be deduced from the definitions of the two

\footnotetext{
Copyright (C 1984 by Law and Contemporary Problems

* Professor of Criminal Justice, and East Asian Languages and Cultures, Indiana University, Bloomington. The author wishes to give special thanks to participants in a seminar at the Centre for Criminological and Socio-Legal Studies, University of Sheffield, for their critical feedback on a draft of this paper, and to Vera Marsh and Andrew Vorder Bruegge for typing.

1. K. Davis, Discretionary Justice: A Preliminary Inquiry (1969); K. Davis, Police DiscreTION (1975).

2. See, e.g., 36 Law \& Comtemp. Probs., Fall 1971, and 37 Law \& Contemp. Probs., Winter 1972.
} 
concepts. Accountability means having to answer for one's actions (or inaction). Accountability is thus synonymous with responsibility. Having to answer for one's actions makes sense only if one could have chosen to do otherwise. Holding accountable one who had no choice of action would amount to holding one to answer for a superior's decision; and, even then, it would entail the premise that the subordinate chose (acted) to allow the superior to prevail.

Discretion, as Davis pointed out, means choice of action. ${ }^{3}$ Hence, accountability implies discretion. Insofar as Davis is correct that West German prosecutors have no discretion-that they merely do as the law dictates ${ }^{4}$-he implies that legislators, not prosecutors, are accountable for the practice of prosecution.

\section{III}

\section{ReCOgNizing Discretion}

Davis's definition of discretion is at once clear, simple, and implausible: "A public officer has discretion whenever the effective limits on his power leave him free to make a choice among possible courses of action or inaction." 5 Sellin's work from the 1930's suggests a different definition. ${ }^{6}$ Then, as now, it was popular to suppose that law-abiding behavior is rule governed, while law-violating behavior is not. Sellin proposed instead that all behavior is rule governed but that, in the course of approval and disapproval, success and failure, in everyday life, each person learns a unique set of norms. To some degree at least, each of us lives in an individual culture bounded by a unique set of social experience. When, for instance, a suspect is arrested by a police officer, one can suppose that, in violating the officer's norms, the suspect adhered to norms of his or her own. In this sense, the violation of law implies a form of culture conflict.

Sellin implies that no actor "is free to make a choice among possible courses of action or inaction," for adherence to norms is the only possibility. One need not literally agree with Sellin in order to draw a major insight from his supposition. Whether public officers have freedom of choice of action (or inaction) can be presumed to be inherently problematic. Within limits, the problem is susceptible to empirical resolution. For example, a previous study conducted by the author of police offense-reporting decisions illustrates false presumptions of discretion by police. ${ }^{7}$ Patrol officers seemingly have great discretion as to whether to file offense reports. Apart from general exhortations to report fully and fairly, officers are given little formal guidance on such issues as whether to believe complainants when there are reasons to question

3. K. Davis (1969), supra note 1, at 4.

4. Id. at 166 passim.

5. Id. at 4.

6. J. Sellin, Culture Conflict and Crime (1938).

7. Pepinsky, Police Patrolmen's Offense-Reporting Behavior, 13 J. Research Crime \& Deline. 33 (1976). 
their veracity or how to interpret "obvious" evidence that gives rise to conflicting interpretations of an event (e.g., whether screwdriver marks on a door indicate that someone intended to commit a felony in a dwelling, or whether there is some other plausible explanation). Other cues that the police receive-such as orders to maximize their visibility on the streets-militate against wasting time on fruitless or trivial reporting and sustain discretion not to file offense reports. The patrol officers observed in this study were confident that their decisions were and had to be largely a matter of individual discretion.

The officers were wrong. Regardless of whether complainants stated offenses, the officers failed to file a report unless dispatchers had named an offense in their calls (e.g., "check a burglary" as opposed to "check a breakin"). When a police dispatcher named an offense in his call to a patrol car, and a complainant corroborated that some offense (even if a different one) had occurred, the officers reported offenses ninety percent of the time. A simple set of decision rules for narrow categories of offenses accounted for the balance of nonreporting. Apparently, in a quasi-military organization with a vague mandate, bureaucratic functionaries unconsciously patterned their behavior to accord with the nearest thing to directives that existed. Did the officers have discretion in Davis's terms? They had very little, in fact. Their major discretion appeared to be over which offense to report, not over whether to report an offense.

Empirically, the inference is that discretion amounts purely and simply to variance in decisions an observer is unable to explain. This empirical result acknowledges that the existence of discretion rests on the method of the observer. Other scientists, such as physicists and chemists, have long since conceded that instruments of measurement are ever capable of confounding empirical tests of their theories. Thus, it should cause social scientists no great loss of face to forsake positivism ("the facts speak for themselves") for empirical realism (theories rest on facts, which in turn rest on the vagaries of measurement). It may well be that today's discretion will, in light of refined measurements of analysis, turn out to be tomorrow's empirical law of human behavior, by definition a discretionary void. Among those of us who are committed to expanding the human power of choice-the exercise of free will-it is seldom recognized that measurement can be designed so as to find greater unexplained variance in social action. Knowledge of how groups of people manage to decrease the predictability of their acts provides a scientific basis for designing and evaluating strategies of social control that expand rather than restrict room for human choice. ${ }^{8}$ For us students of discretion, then, it is important to recognize that the existence of discretion rests ultimately on how we and others look for it and that, as Davis acknowledges, the existence of discretion may be a blessing. ${ }^{9}$

8. Pepinsky, Humanizing Social Control, 6 Humanity \& Soc'y 227 (1982).

9. K. DAvis (1969), supra note 1 , at 19. 
Some will protest that it is overly behavioral to define discretion as unexplained variance. However, the definition precludes the possibility that groups of people happen to make the same choice under similar circumstances. It also precludes the possiblity that people who behave in unexpected ways do so without thinking through their action and making any rational choices. Some thinkers argue that the observer must delve into the minds of actors to see what rational options they considered. ${ }^{10}$ But this sends the observer into an infinite regress. Were the patrol officers in my study reporting their true thought processes? Were they deceiving even themselves about the choices they made? If they had claimed that they had the option of reporting offenses when the dispatcher had named none, would they have been deceiving the observer or themselves-by laying claim to greater power than they actually had? These issues have no empirical solution. The only testable propositions about choice rest on what people do, not on what they or observers claim that they might have done instead. Nor can one test propositions about whether behavior is unintended. "Determinism" and "free will" are arbitrary constructs. Those who posit absolute determinism can always claim that there are external causes of behavior which have not yet been found. Those who posit absolute free will can always claim that there remain choices not yet found. In scientific parlance, theories of choice and discretion remain trivial unless they include an empirical test of competing claims.

The behavioral test of discretion can be justified on prudential as well as empirical grounds. Insofar as actors manage to do what observer-scientists do not expect, the actors provide the observers with options that the observers can attempt to make plausible, practical, and rational. Explanations of previously unanticipated action can justify options for those who previously were locked into behaving predictably. The quest to understand unexplained variances in behavior is a quest to expand knowledge of rational options that similarly situated actors have. In my study of police crime reporting, police reported offenses in response to just four of the more than two hundred calls in which dispatchers named no offense. If we could make cognitive sense of the four exceptions, we might give patrol officers the tools to approach a fiftyfifty split between reporting and not reporting offenses in response to calls with no offense named. The police would thereby demonstrate greater power

10. Beyleveld \& Wiles, How to Retain Your Soul and Be a Political Deviant in Deviant InTERPRetaTIONS (1979), make an especially thoughtful case for the prosposition that choice can be deemed free only when action can be shown to be rational within known environmental constraints. They argue forcefully that inference of whether action is rational does not entail infinite regress. This author disagrees. The range of controversy outlined in Rationality (B. Wilson ed. 1979), illustrates why. Determination of whether an action is rational entails selection from among several open sets: selection of relevant elements from the potentially infinite set of environmental constraints, selection of elements of logic from a potentially infinite set of systems of logic, and choice of a stopping point in a potentially infinite inquiry as to whether an actor's account of an action is true or false. Thus, as in comparative research, the observer always has the potential of choosing between premises that lead to defining another's action as either rational or irrational. See H. Pepinsky, Crime and Conflict: A Study of Law and Society 8-10 (1976). 
of choice in reporting behavior and less constraint from the content of police dispatchers' calls. If we believe in promoting free will or choice, we should be happier as behavior becomes less predictable.

IV

\section{DisCRETION AND JUSTICE}

There is good discretion and bad discretion. If a police officer shot and killed a person for making a raspberry at the officer, the killing would be unexpected and hence discretionary. The killing would also constitute a tragic injustice to practically all of us. But it is crucial to recognize that, although discretion can be exercised unjustly, there can be no justice without discretion.

Class (or racial) bias is the most prominent issue of (in)justice in criminological literature on police discretion. How is class bias demonstrated? It appears as a systematic difference between the treatment that members of each of two or more classes receive at the hands of police. In statistical terms, the difference in treatment has to be "significant" in order to demonstrate bias, and statistically significant differences-"explained variance" from null hypoptheses-are by definition systematic. Class-biased police fit a mold; they fail to exercise discretion to respond to citizens without reference to class. As Aubert has put it, chance needs to be built into legal decisionmaking before we can accept the decisions as just. ${ }^{11}$

A graduate student once unwittingly demonstrated that discretion is only half of the equation for justice. In her term paper, she criticized sexual disparity in sentencing, and concluded that the quality of sentencing would be improved if more women were sent to prison. She argued that such equality was a fundamental right of women. The problem with her remedy, of course, was that it would have represented a diminution in the power of an admittedly oppressed class, rather than an increase in the accountability of officials to women. The quest for women's rights before male-dominated officialdom ought to be to make officials equally accountable to men and women, not equally oppressive to men and women. To attain justice, accountability needs to be added to discretion.

In the realm of policing, accountability means that those who police are answerable to the interests of those who are policed. If young black men could be shown that they were no more or less likely to be arrested than others, and that police took as much account of the interests of the young black men they did arrest as they took of others' interests, then those arrested would be more likely to believe that the arrests were just.

11. Aubert, Chance in Social Affairs, 2 InQuiry 1 (1959). 


\section{Class Injustice in Law Enforcement}

In recent years, there has been considerable debate over whether class bias in policing is socially significant. For example, controlling for prior record and offense charged, Terry ${ }^{12}$ and Thornberry ${ }^{13}$ found the same level of statistical association between class and police decisions to take juveniles into custody (Kendall's tau - .04). Terry dismissed the association as insignificant; ${ }^{14}$ Thornberry reported the association as a major finding. ${ }^{15}$ Statistical significance of a result is one thing, and theoretical significance is another. Theoretical significance is the point over which these two researchers diverge.

Robison was the first to find that American police discriminated against youths "from the wrong side of the tracks." 16 From what is now known, such discrimination is initially minimal, especially as policing since the latter 1950 's ${ }^{17}$ has grown reactive. ${ }^{18}$ It appears that the dramatic difference in rates of crime and criminality are somehow attributable to differences in rates of citizen complaints among neighborhoods. ${ }^{19}$

Consider, though, how these initial marginal differences are compounded. The poor or minority youth is slightly more likely to be taken into formal custody and to be referred to juvenile court for a first offense. ${ }^{20}$ Then, the offender becomes at risk (a) from other officials such as probation officers, (b) from investigators who may focus suspicion on suspects because of prior record, and (c) if apprehended again, from the whole criminal justice system-including police, prosecutors, probation officers, referees, judges, and parole officials, who will all discriminate, even to the extent of levying heavier charges against those with prior records. ${ }^{21}$ Thus, the slight initial discrimination creates and extends prior records, and ultimately leads some classes to have highly disproportionate representation among hardened offenders. A study of reconviction by the British Home Office Statistical Unit $^{22}$ dramatically illustrates the increasing liability of those who enter the

12. Terry, The Screening of Juvenile Offenders, 58 J. Crim. L., Criminology \& Police SCI. 173 (1967).

13. Thornberry, Race, Socio-Economic Status and Sentencing in the Juvenile Justice System, 64 J. CRIM. L. \& Criminology 90 (1973).

14. TERRY, supra note 12 , at $179-180$.

15. ThORNBERRY, supra note 13, at 97-98.

16. S. Robison, Can Delinguency Be Measured? (1936).

17. Selke \& Pepinsky, The Politics of Police Reporting in Indianapolis, 1948-78, 6 LAW \& Hum. BEHAV. 327 (1982).

18. A. Reiss, The Police and the Public (1971). Nowadays, the police depend on rich and poor complainants alike to tell them what to do, rather than relying heavily on their own initiative to pick up people off the street.

19. R. Carr-Hill \& N. Stern, Crime, the Police and Criminal Statistics (1979).

20. See supra notes 12 and 13 .

21. Studies like Terry's, supra note 13, reflect consensus among criminologists and criminal justice officials that prior record is a legitimate, "legal" basis for deciding that an instant offense is more serious than it otherwise might be perceived to be.

22. The British Home Office Statistical Unit, The Sentence of the Court (1964). 
criminal justice system: overall, $36.2 \%$ of first offenders are reconvicted within five years, $57.5 \%$ of second offenders, and $77.2 \%$ of fifth offenders.

Once Robison had found discrimination in law enforcement, it fell to Tannenbaum ${ }^{23}$ to explain how a little discrimination could go a long way. Practically all youths periodically do things that could be treated as delinquent. ${ }^{24}$ The police catch only a few. Once a youth is caught and labelled (albeit more gradually and softly than Tannenbaum might imply), his social identity is transformed from that of a normal kid who occasionally misbehaves, to that of a delinquent who only incidentally behaves normally. Even a slight class bias in initially apprehending offenders can result ultimately in a highly select and biased officially created sample of delinquents (and ultimately of adult criminals). The prophecy that criminals are poor, young, and male ultimately fulfills itself.

The insight that a little bias goes a long way has two major implications that underlie inquiries into all criminal justice discretion. First, as Swigert and Farrell ${ }^{25}$ point out, it is absurd to presume that decisions are unbiased insofar as they are accounted for by so-called "legal variables"-prior record and offense charged. ${ }^{26}$ Second, the greatest potential for the injustice of selective enforcement lies not in individual police decisions, but in the cumulative interaction of decisions among police, other criminal justice officials, offenders, and the more or less tolerant civilian world around them. Thus, Davis's premise-that primary concern should be reserved for the impact of individual parties' bias on justice ${ }^{27}$ _rules out consideration of the more crucial issues of discretion and justice.

There is overwhelming class bias, too, in the way police are mobilized. This point can be illustrated with a politically implausible but legally reasonable hypothetical case. Suppose that in an American city with team policing, an officer assigned to cover a district totally at his discretion decides to leave calls for service to back-up patrol. In lieu of routine patrol, the officer decides to "patrol" to look for crime in a city hospital in the district. Suppose further that under the public records law of the jurisdiction the hospital's records are open to free inspection. Having had paramedical training, the officer decides to look through surgery records for the prior year. The officer finds that one general practitioner has performed an unusual number of hysterectomies. The officer interviews a number of the patients to obtain their case histories, and in one case, in which the patient died on the operating table, interviews the family. The officer reviews the case histories in light of excerpts from pathology texts and of consultation with doctors. Eventually, the officer

23. F. Tannenbaum, Crime and the Community (1938).

24. See Porterfield, Delinquency and Its Outcome in Court and College, 49 Aм. J. Soc. 199 (1943). Selfreport studies since Porterfield's have consistently validated this finding.

25. Swigert \& Farrell, Normal Homicides and the Law, 42 AM. Soc. REv. 16, $21-23$ (1977)

26. Terry, supra note 12 , is an early representative of the dominant perspective that the heavy influence of seriousness of offense charged and prior record rules out class bias in criminal justice decisionmaking.

27. K. Davis (1969), supra note 1, at 231. 
decides that ten of these operations, including the one in which the patient died, were clearly unnecessary, and that the patients were not so informed. Armed with affidavits from those interviewed and from consulting physicians, the officer asks a judge to issue a warrant for the doctor's arrest on nine counts of aggravated assault and one count of involuntary manslaughter. ${ }^{28}$

The case illustrates several points. First, it is highly unusual, but legally possible, for much of police patrol to be done in the suites instead of the streets. ${ }^{29}$ Second, as Reiman points out, there is much reason to believe that more death, injury, and property loss result from white-collar and organizational crime than from street crime, so that equal enforcement of the law would require the police and others to report and act more against rich people than poor people. ${ }^{30}$ Third, given that the crimes of the rich are far harder to detect and gather evidence against than those of the poor, ${ }^{31}$ it might well take something like nine officers to discover and punish a rich person's crime for every officer who brings a comparable street criminal to justice.

If, then, the rich are to be no more selected for non-enforcement of the criminal law than the poor, the vast majority of the 400,000 sworn officers in the United States would have to be sent to patrol the suites rather than to patrol the streets, not only to give offenders their just desserts, but also to protect victims. ${ }^{32}$ Yet the reverse is true, as everyone knows, and the police and the public largely take this highly selective allocation of patrol resources for granted. ${ }^{33}$

28. See Sutherland, White-Collar Criminality, 5 AM. Soc. REv. 1 (1940), which long ago pointed out that society is predisposed to see white-collar wrongs as civil or administrative rather than criminal. Thus, a doctor whose unnecessary surgery results in injury or death might ordinarily be seen as guilty of malpractice, but not of a crime. But consider: Harmful contact on one who has not consented constitutes the common law crime of assault, and, at common law, an assault that results in death constitutes manslaughter, if not murder. It is increasingly recognized that true consent requires that a patient be fully informed about the risks and necessity of surgery. If, then, a doctor fails to inform a patient that proposed surgery is unnecessary, the patient can be said not to have given informed consent to the surgery; hence, the surgery can be said to constitute criminal assault.

29. The phrase "crime in the suites" is now commonly used by students of white-collar crime. It is said to have been coined by Ralph Nader some years ago, although a reference to the first use of the term has not been found.

30. J. Reiman, The Rich Get Richer and the Poor Get Prison (1979).

31. See, e.g., Sutherland, supra note 28.

32. Federal Bureau of Investigation, Crime in the U.S.: Uniform Crime Rep. (annual) consistently reports about $\$ 6$ million per year losses from property crime, and nearly 20,000 deaths from murder and non-negligent manslaughter in a year. By contrast, the annual loss from auto repair fraud alone is estimated at $\$ 20$ billion (Jesilow, Deterring Automobile Repair Fraud: A Field Experiment (1982) (unpublished Ph.D. dissertation)), while annual deaths from unnecessary surgery alone are estimated to be 14,000 (see Reiman, supra note 30). Reiman also reports annual deaths from unsafe products and working conditions. It makes intuitive sense that the rich do far more unlawful harm to victims than the poor. The rich have more power to do so, and can do so with relative impunity.

33. M. Brogden, The Police: Autonomy and Consent (1982), illustrates a general phenomenon in a case study of policing in Liverpool. From the working classes to the highest social strata, there is broad consensus that the major crime problem, upon which the police ought to concentrate, is that posed by the chronically unemployed underclass, notably by young men in that group. Even Karl Marx, in the Communist Manifesto (1848), lambasted "the 'dangerous class', the social scum, that passively rotting mass thrown off by the lowest layers of society." The myth that crime is associated with poverty is incredibly pervasive. 
Since we are unwarranted in believing that poverty has anything to do with making some people less law-abiding than others, virtually every theory in the criminological repertoire of what causes crime is ill founded. ${ }^{34}$ Whether biological (as in theories of heritability or malnutrition), psychological (as in theories of ego development or moral development), or social (as in theories of trouble in school or in the family, or of status attainment, or of ecology), practically all (even Marxist) theories rest on accepting a correlation between crime and poverty. ${ }^{35}$ Together, our theories and law enforcement predicated upon those theories amount to a self-fulfilling prophecy in which we have a huge social investment. As a consequence, to borrow the title of Reiman's study, the rich get richer and the poor get prison. ${ }^{36}$

\section{VI}

\section{Practical Import of Selective Law Enforcement}

On the one hand, the overwhelming class bias in law enforcement makes it overwhelmingly both unjust and ineffectual. Most harm comes from crimes committed with impunity and, even where offenders are punished, that punishment costs taxpayers a great deal ${ }^{37}$ with little protection or aid provided to past or future victims. ${ }^{38}$

On the other hand, law enforcement is not realistically subject to being made equitable or effectual, or of being abolished. Law enforcement is literally a political exercise-an exercise of power-and in that exercise those who have more power as citizens are odds-on favorites to avoid the force of law. ${ }^{39}$

Even within the realm of controlling poor street criminals, and even assuming the validity of theories by which retribution, deterrence, incapacitation, and rehabilitation through law enforcement are believed to prevent crime, putting more resources into policing and criminal justice in a society with a large crime problem simply makes the goals of retribution, deterrence, incapacitation, or rehabilitation less attainable. ${ }^{40}$ But, as with other processes in living organisms, social processes are generally not reversible. ${ }^{41}$ Although more policing ultimately produces more crime and criminality, ${ }^{42}$ withdrawal of policing will ultimately achieve the same result. We have seen that disorder breaks out during police strikes, ${ }^{43}$ so that withdrawal of policing can be

34. See Sutherland, supra note 28.

35. H. Pepinsky, supra note 10 , at 108-10.

36. J. Reiman, supra note 30 .

37. According to the U.S. Bureau of Justice, Expenditure and Employment Data for the Justice System (annual), about $\$ 100$ per year per American is spent for police and corrections alone. The courts and public lawyers are relatively cheap.

38. H. Pepinsky, Crime Control Strategies: An Introduction to the Study of Crime (1980), is an empirical and theoretical defense of this thesis.

39. Id. at $222-23$.

40. Id.

41. G. Bateson, Mind and Nature: A Necessary Unity (1979).

42. See H. Pepinsky, supra note 38.

43. Hutchins, Comment on H. Pepinsky's Toward Diversion from Diversion from the Criminal Justice System (1973) (unpublished paper presented at the Second Criminal Justice Conference at 
expected to engender a political will to strengthen policing more than ever. For the time being, the optimal course would seem to be neither to add nor to subtract police forces. The question remains whether inherently unjust and ineffectual policing can be so directed as to encourage civilians gradually to manage to do without law enforcement, in a way that lessens the injustice and the harm of crime.

Contrary to the thrust of Davis's arguments, reduction of the most glaring injustice requires that we INCREASE the discretion of the police NOT to enforce the law. This entails establishing a system of regulation (1) to give greater discretion to police, and (2) to make their discretionary action accountable to those most susceptible to having the law enforced against them.

\section{VII}

\section{INCREASING DISCRETION}

"Theories of public law have tended to see discretion as a void surrounded by legal rules and principles." 44 A corollary to this presumption is the belief that when rules are promulgated and heeded, discretion is restricted. These presumptions rest on faith rather than experience. Actually, public regulation is a good way to increase official's discretion.

The rules set forth in Miranda $v$. Arizona ${ }^{45}$ and their aftermath are a good illustration. The Miranda Court was faced with two related problems in 1966. The Court found first that police were systematically coercing confessions out of suspects despite the constitutional privilege against self-incrimination, and second that the police lacked guidance as to what safeguards against coercion were required of them. The Court's solution to the first problem was to extend the exclusionary rule to cover all coerced confessions. Its solution to the second problem was to lay down a set of rules which would be conclusively presumed to draw the line between the circumstances under which confessions were or were not coerced.

It appears that the rules and the sanction had little impact either on rates of confessions or on rates of conviction following arrests. ${ }^{46}$ If the Court presumed that Miranda would shift the balance of police/suspect power in favor of suspects, it was mistaken. More intriguing for our purposes, the Court was also mistaken in believing it clarified for police what behavior was expected of them. A perusal of Shepard's Citations shows that a mass of controversy rapidly emerged on the meaning of every provision of the rules: this controversy began to subside only at the close of the decade after the Miranda decision. In a revealing critique of the exclusionary rules, the Chief and General Counsel of the Washington, D.C., Metropolitan Police argued in 1971 that "[p]olice

\footnotetext{
the Center for the Study of Democratic Institutions, available at the Robert M. Hutchins Center for the Study of Democratic Institutions, Santa Barbara, California).

44. Prosser, The Politics of Discretion, in Discretion and Welfare 148 (1981).

45. Miranda v. Arizona, 384 U.S. 436 (1966).

46. Pepinsky, $A$ Theory of Police Reaction to Miranda v. Arizona, 16 Crime \& Deling. 379 (1970).
} 
officers want to be told what to do," 47 and criticized the rules for being unclear.

The ambiguities posed by the Miranda rules are practically limitless. They include: whether a suspect who responds to a police request to come to the stationhouse to answer questions is "in custody"; whether the "right to remain silent" extends to giving one's name and address; whether police are required to inform a suspect that anything said "will" be used against him or her in a court when in fact it may be used in mitigation; whether the "right to have counsel present" covers every interval of interrogation; who decides whether a suspect "cannot afford" to retain private counsel; whether a suspect who has refused to be questioned on one matter may be approached on another; whether a waiver of rights must be acknowledged in writing or on tape; whether the warnings must be presented in writing rather than orally; and whether a suspect is mentally competent to waive rights.

Over the years, in each jurisdiction, the police had a chance to work out implicitly with prosecutors and judges what kinds of interrogation or reports of interrogation would be tolerated. While the Miranda Court may have been outraged at some of the practices recommended in interrogation manuals, in the cases before it, it is likely that police practice had become remarkably uniform by 1966, so that in any situation, local officials at least could have expected to agree on whether an interrogation had gone beyond the bounds of propriety. This kind of uniformity represents what Schelling describes as tacit bargaining in games theory, ${ }^{48}$ and what Sudnow describes as "normal crimes" as between public defenders and prosecutors in plea bargaining. ${ }^{49}$ In common parlance, we know such uniformity as customs.

Legislation or rule-making may have two outcomes. It may be perceived as codifying custom, in which case it ratifies rather than changes behavior. Ratification of custom, as in the achievement of consensual statements of principle in Quaker meetings, can strengthen a group's sense of solidarity and its sense of opposition to outsiders. ${ }^{50}$ On the other hand, if the aim of rulemaking is to control or change behavior, then the more specific and encompassing the rules, the more imposition of the rules breaks down custom, that is, creates discretion. ${ }^{51}$ The confusion created in the wake of Miranda cannot simply be attributed to poor drafting. Quite the opposite is true. If the rules had appeared from the outset to be ambiguous or obscure, judges could have been expected to adopt the "good faith" test that has only become prominent during the last several years. ${ }^{52}$ The application of such a test would forgive police officers for doing what arguably was legitimate and

47. Wilson \& Alprin, Controlling Police Misconduct: Alternatives to the Exclusionary Rule, 36 LAW \& Contemp. Probs. 488, 493 (1971).

48. T. Schelling, The Strategy of Conflict (1960).

49. Sudnow, "Normal Crimes": Sociological Features of the Penal Code in a Public Defender's Office, 12 Soc. Probs. 255 (1965).

50. L. Coser, Functions of Social Conflict (1956).

51. Pepinsky, Discretion and Crime Legislation, in Discretion and Control 27 (M. Evans ed. 1978).

52. E.g., United States v. Williams, 622 F.2d 830 (5th Cir. 1980). 
fail to find that police had abused their discretion in conducting interrogations. The tendency of judges would have been to presume that adherence to preexisting custom was acceptable and reasonable.

Those who promulgate rules to curtail discretion are doomed to frustration. To be sure, new customs of interpreting rules will eventually take hold, and this development will appear to indicate that conformity to the rules has been established. But while customs of rule-abiding behavior can eventually be inferred, the form of the customs will be indeterminate and unpredictable at the time the rules are promulgated. The harder rulemakers try to dictate the behavior of police officers, the more discretion the officers will have concerning what adherence to the rules requires.

\section{VIII \\ Channeling Discretion Through Accountability}

Political debate rages between advocates of police professionalism and proponents of community responsiveness. ${ }^{53}$ Where professionalism prevails, police are more likely to trust one another as justly exercising individual discretion, while citizens who have the most contact with the police are likely to perceive police discretion as threatening and unjust. Where community responsiveness reigns, outside police are more likely to distrust the local agency as corrupt. Two sets of citizen perspectives are possible within a community where responsiveness prevails. Either the citizens are split into factions that view the police as allies or enemies, in which case discretion is curtailed and injustice is felt by citizens in the "enemy" faction, or citizens help create rules that generate police discretion and stand a chance of being united in the belief that their own policing is just-while believing policing in other communities to be less so. In this last instance, the police can be expected to exercise discretion with restraint and with reluctance to invoke law. These three patterns of policing correspond roughly to Wilson's legal, watchman, and service styles. ${ }^{54}$

We have a great deal of experience in creating the legal and watchman patterns of policing. Variants of centralized rulemaking or quasi-regulation of policing across jurisdictions, such as commission reports, ${ }^{55}$ standards, ${ }^{56}$ and common training programs, have taken policing a long way toward professionalism or legalism much as the creation of uniformed forces to protect

53. This debate is as strong in Britain as it is in the United States and, as Brodgen, supra note 33 , shows, has a long history. Most importantly for the argument presented here, the direction policing takes rests crucially on organizational incentives. Incentives to professionalism emerge starkly in the case study by Jones \& Winkler, Beyond the Beat: The Facts About Policing in a Riotous City, 9 J. L. \& Soc. 103 (1982).

54. J. Wilson, Varieties of Police Behavior: The Management of Law and Order in Eight Communities (1968).

55. E.g., President's Commission on Law Enforcement and Administration of Justice, Task Force Report: The Police (1967).

56. E.g., National Advisory Commission on Criminal Justice Standards and Goals, The Police (1973). 
commercial interests in the nineteenth century went a long way toward establishing the watchman or the order-maintenance pattern. ${ }^{57}$ By contrast, service policing appears to have been largely isolated and peculiar to small and wealthy communities in which the police obviously serve at the pleasure of citizens of uniformly high class standing. ${ }^{58}$

Since law enforcement is inherently class-biased, the economic injustice of law enforcement stands to be reduced only as police become more oriented toward service other than law enforcement in rich and poor communities alike. It has been said that law enforcement cannot be accomplished by withdrawing police from communities that have come to depend on them, that resultant predation and violence will only redouble community sentiment for law and order. Going further, police initiatives are statistically incapable of demonstrating either success in crime prevention or greater responsiveness to the needs and complaints of victims of crime without sacrificing the one at the expense of the other. Whatever initiative succeeds, an enduring reduction in law enforcement class bias must come from the private community, and the police must merely follow. 59

One procedure for making discretionary policing accountable to communities has been outlined elsewhere. ${ }^{60}$ Most urban departments today have community relations officers, who are largely relegated to giving invited talks. Patrol district by patrol district (it is best to proceed slowly, and to experiment freely and gradually), the community relations officer could try to locate established groups that represent, as much as possible, the district and its interests. For example, neighborhood associations in some cities (such as Pittsburgh and Indianapolis) are well established and stand out as representative groups. The community relations officer could arrange that by rotation (with backups provided for out of service officers), patrol officers in the district would come in to negotiate mutually agreed-upon criteria for police performance. In open meetings, the group and other community members would tell the police what services they wanted, and the officers would tell the citizens what they could and could not reasonably do. From the outset, it would be established that the agenda for discussion included only what the police could do for citizens and how police performance might be measured, not what the community could do for the police (as by establishing block

57. See, e.g., E. Monkkonen, Police in Urban America, 1860-1920 (1981).

58. See J. Wilson, supra note 54. Wealthier communities lend themselves to service-style policing for several reasons. First, the young people of the communities come from families with too much power for the police to succeed in treating young residents as ordinary criminals. Second, the communities have the money and status to attract high-status recruits, as by requiring college degrees. Third, wealthier communities have often proven willing to have experimental programs in policing. For instance, while I was living in the Twin Cities area more than a decade ago, one suburban department had its officers trained in Adlerian therapy and, much to the delight of the community residents, offered confidential counseling for what elsewhere might have been deemed crime problems between parents and adolescent children.

59. H. Pepinsky, supra note 38, at 143-67.

60. An earlier version of the proposal outlined here appears in Pepinsky, Police Decision-Making, in Decision-Making in the Criminal Justice System: Reviews and Essays (M. Gottfredson ed. 1975), and Pepinsky, Goal Definition for Police Patrolmen, in Working with Police Agencies 32 (1976). 
watches). ${ }^{61}$ The aim would be to establish that citizens were initiating responses from police, rather than the police initiating responses from citizens.

Periodically, community representatives would propose concrete objectives for policing and procedures for measuring police progress in meeting those objectives. These objectives and procedures might have nothing to do with traditional law enforcement. For instance, an objective might be for officers to meet members of the community in routine visits, and the procedure might be for members of the community to circulate monthly surveys asking residents whether they had talked with individual officers whom they could name during the period, how often, and concerning what. Community members would volunteer their labor to conduct and tabulate the survey, while the police department bore the expense of preparing the instrument. Officers would be invited to see and discuss survey results, and to respond to them orally or in writing.

Each objective and measure would be subject to approval by both community members and the officers involved. The police could make counterproposals. To establish mutual trust, it would be best to require complete consensus on standards among officers (in consultation with superiors) and the community members who attended meetings, before community representatives and the head of the police department signed an agreement (subject to renegotiation) enacting the measure and its objectives. ${ }^{62}$

The process of accumulating objectives and measures could be openended. There would be no need to settle on a "full and final" set of objectives and measures. Meetings and negotiations could be a continuous process arranged between a community liaison representative and the district police supervisor.

For their part, the police would undertake to include objectives, measures and tabulations, and other analyses of results from the community in each officer's personnel record. Once the process was underway, the police might also undertake to limit information about the officer's performance included in the file to (a) that provided by the community, and (b) information from the police department only on disciplinary action and citizen complaints. ${ }^{63}$ That is, community indices of performance would supersede traditional performance measures such as arrest figures. When police boards were deciding

61. If communities are to take the initiative in managing conflict, community groups rather than police must take the initiative in setting the agenda of police-community interaction. Having police set the agenda is the fundamental flaw in most police-community relations efforts.

62. The requirement of police consent to objectives would also protect outsiders and minorities within the community against community bigotry and intolerance. Since the police are held accountable to larger constituencies (e.g., to the mayor of a city if the mayor appoints the chief, to the courts for protection of citizens' civil rights, and to the media), they could be expected to moderate community extremism. In anthropological terms, this would amount to using crosscutting ties to control violence and conflict. See H. Pepinsky, supra note 38, at 109-10.

63. Id. This limitation would also serve to protect outsiders and minorities against community extremism. The inclusion of disciplinary action and citizen complaints would guard against police violations of citizens' civil rights. 
issues like promotion, performance evaluations would be restricted to information in the personnel file. It would thus be clear that community assessment of policing carried serious weight in personnel actions.

This kind of approach to controlling policing would increase police discretion both among districts and within districts. Discretion among districts would be increased insofar as community objectives and measures provided varying cues as to community expectations. Discretion within communities would be increased by emerging community standards of performance measurement, just as the Miranda decision increased police discretion in interrogation across the country. Because the process of setting standards would be open-ended, customs of policing would continuously be unsettled. It could be expected that the ways that different officers approached various situations within a district, with the objective of engendering the good will of community members, would vary considerably and unpredictably. If the approach succeeded in establishing substantial bonds of trust between officers and community members, discretion both in officer behavior and in community evaluation would be equated with justice rather than seen as threatening. The room for discretion would be seen as a challenge to the constructive resourcefulness of all concerned in satisfying one another's concerns and interests.

Although some communities might call for crackdowns on "criminal elements" from time to time, especially initially, the approach should generally, if only gradually, lead to a diminution of law enforcement in each district, for two reasons. First, one gains the impression that police often arrest simply for lack of an alternative. ${ }^{64} \mathrm{~A}$ net effect of the approach would be for police to get to know community members better without the urgency and unpleasantness of having to resolve complaints of the moment. ${ }^{65}$ In encounters in which the police confronted people they knew from other circumstances, they could on the whole be expected to feel better equipped and more confident about proposing idiosyncratic informal resolutions to disputes. ${ }^{66}$

64. This problem is general to criminal justice officials. When I did public defender work as a law student in the 1960's, I found sentencing judges most receptive to probationary alternatives such as arrangement for private therapy. One judge expressed relief that I had presented him an option to sending a sex offender to a notorious hospital for the criminally insane. Similarly, one police department in my present community has embraced the opportunity to issue summonses for minor offenses instead of going to the trouble of arresting and booking suspects. In part, arrests and other sanctions are imposed simply because officials see no other way to handle situations.

65. The extent of pleasant, informal contact with citizens is something for which rural English constables formerly were, M. Cain, Society and the Policeman's Role (1973), and Japanese police currently are, D. Bayley, Forces of Order: Police Behavior in Japan and the United States (1976), renowned.

66. Felstiner, Influences of Social Organization on Dispute Processing, 9 L. \& Soc. REv. 63, 87 (1974), argues that American conflict managers lack the intimacy that helps mediators propose successful resolution of conflicts in other societies. The mechanism of accountability proposed here is designed in part to help create that intimacy. Citing societies in which resort to law enforcement is practically nonexistent, one author infers that depth of personal knowledge of subjects, sharing power with subjects, vulnerability to subjects, and mutual interdependence.with subjects restrain punishment of offenders. N. Christie, Limits to Pain (1981). 
Second, people complain to police for lack of an alternative. ${ }^{67}$ As a secondary effect of people working together on a common enterprise, especially one implying that community representatives were competent to control policing, community members (a) could be expected to gain confidence enough to handle more disputes for themselves, and (b) would have identifiable community representatives other than the police to turn to for informal mediation of disputes in time of need. ${ }^{68}$

A turning from law enforcement to informal handling of disputes within communities implies a lessening of class bias. Most police districts are relatively homogeneous in class, and victimization studies have found that most street crime occurs between offenders and victims of like class standing. ${ }^{69}$ Moreover, informal resolution of disputes through mediation tends to reintegrate offenders back into groups rather than labeling and further isolating them in the manner of criminal justice processing. ${ }^{70}$ Bias can occur in informal dispute resolution, to be certain, such as between old and young or men and women. But whatever class bias occurred in handling disputes informally within police districts could in no way reach the proportions of class disparities in law enforcement. Although injustice in dispute handling is potentially an infinite regress, it would regress downward to a lower level as law enforcement waned. The net result would be that the generation of police discretion would reduce the selective injustice of law enforcement.

\section{IX \\ Conclusion}

Police discretion has been too glibly criticized in recent years. For one thing, much of what is taken to be discretion is selective law enforcement, a process which is nondiscretionary. For another, discretion is necessary to reduce the injustice of law enforcement. Reducing the non-discretionary class bias inherent in law enforcement entails reducing resort to law enforcement itself, which entails generating greater discretion both among police districts and agencies and among individual officers within districts.

Misleading premises about police discretion stem from uncritical adherence to an Enlightenment idea of law and order. ${ }^{71}$ Enlightenment misconceptions run thus: The terms of a people's social contract among themselves place limits on the exercise of state power over the people. To ensure that people respect one another's liberty within the terms of the contract, officials are to invoke legal sanction for misbehavior with perfect discipline-swiftly,

67. Pepinsky, Reliance on Formal Written Law, and Freedom and Social Control, in the United States and the People's Republic of China, 26 BrIT. J. Soc. 330 (1975).

68. See id.

69. See, e.g., M. Hindelang, M. Gottrredson, \& J. Garafalo, Victims of Personal Crime: An Empirical Foundation for a Theory of Personal. Victimization (1978).

70. Li, Law and Penology: Systems of Reform and Correction, in China's Developmental. Experience 144 (Oksenberg ed. 1973).

71 . In the realm of criminal law, the Enlightenment perspective was most clearly and cogently argued by C. Beccaria, On Crimes and Punishments (H. Paolucci trans. 1968). 
surely, and just severely enough to make the cost of breaking the law marginally greater than the gains offenders seek. The official who acts within the bounds of law will apply the law equally to friend, foe, and neutral stranger. This government of laws and not of people preserves civil liberties and avoids state despotism. By making law enforcement predictable, the government of laws leaves people free to undertake private obligations freely and with the security that reciprocity will be upheld. ${ }^{72}$ The health and vigor of private enterprise rests on the security that the rule of law will be upheld. Hence, not only civil liberties but economic health and growth of peoples rest on maintenance of law and order.

These premises entail two basic fallacies. One is that imposition of rules makes behavior less discretionary, more predictable. As we have seen in the case of the Miranda rules, imposition of rules instead breaks down custom and introduces ambiguity into law enforcement. Application of rules requires (a) that inferences be drawn from information received (e.g., as to whether complainants are telling the truth), and (b) that the rules be interpreted in light of unforeseeable ambiguities presented by idiosyncratic encounters. Extra-legal interpretation of the meaning of rules in practice-personal evaluation of circumstances in light of law-is unavoidable. To take one example, there is no such thing as an objective measure of whether penal law has been violated. Trends in crime rates may be taken as an index of changes in perception of how much law enforcement is called for, but not as an index of changing probabilities of unlawful behavior per se, as increasing contradictions among growing numbers of indices of crime and criminality have indicated. ${ }^{73}$

The other fallacy is that more rigorous law enforcement can equalize chances of enforcement across classes. The capacity of people to shape officials' evaluations-both of whether crimes have occurred and of the seriousness of crimes that have occurred-is inherently a matter of power. The odds of immunity from law enforcement favor those with greater power, or higher class standing, in any society. Equal chances of law enforcement would require that far more official resources be devoted to scrutiny of the activities of those at the top of the class hierarchy than of those at the bottom, a political absurdity. ${ }^{74}$

The idea of full enforcement is even more chimerical. Self-report studies of street crime, let alone studies of white-collar and organizational crime, indicate that practically every American arguably commits crimes repeatedly. Full enforcement would necessitate that just about all Americans of legal age,

72. This is the essence of organic solidarity, as described by E. Durkhem, The Division of LABOR In Society (Simpson trans. 1949).

73. Pepinsky, Toward a Science of Confinement, Out of the Fallacy of the Counterroll, in Criminology, in Rethinking Criminology 35, 38-40 (H. Pepinsky ed. 1982).

74. Contrary to the author's conclusions here, Braithwaite, Paradoxes of Class Bias in Criminal Justice, in Rethinking Criminology 61 (H. Pepinsky ed. 1982), argues for reversing the bias. It strikes me that the bias can be overcome only by political revolution, and then for no longer than a generation, as has been the case in China. Pepinsky, A Season of Disenchantment: Trends in Chinese Justice Reconsidered, 10 INT'L J. Soc. \& L. 277 (1982). 
including officials, be jailed or imprisoned periodically. In one sense, Davis is right. Selective nonenforcement of the law is far greater than selective enforcement. But this is not a matter of choice. The police are incapable of more than skimming the surface of the pool of potential law violators. The only way to reduce the odds that the rich get richer while the poor get prison is to increase non-enforcement. As law enforcement approaches zero, so does the disproportionate suffering of the poor at the hands of the police. ${ }^{.5}$ Just as the growth of policing in recent years has taken discretion out of the hands of the police, ${ }^{76}$ so attenuation of the injustice of law enforcement requires giving greater discretion to the police not to enforce the law.

Ultimately, our misconception of issues of police discretion stems from an equation of freedom of choice with individual autonomy. Choice is mistakenly presumed to be precluded where action is guided by the expectations of others (as embodied, for example, in law); choice is presumed to be absolute where expectations by others are uncodified.

Symbolic interactionists like Mead have made clear that action without reference to expectations of others is not action at all. ${ }^{77}$ At best, it is asocial behavior. ${ }^{78}$ Once behavior becomes meaningful, it becomes social, and once it becomes social, behavior is guided by perceptions of others' expectations.

Discretion or, in Davis's terms, the power to choose among courses of action or inaction, is thus as fully influenced by people as is selective, or nondiscretionary, decisionmaking. Discretion is as much a product of social control as is selective decisionmaking. Generally speaking, insofar as control operates by leaving rules alone, control creates the conditions for police to settle into customs of enforcement and thus to lose discretion; insofar as we introduce new regulation into policing, we create police discretion.

Non-discretionary or selective law enforcement is inherently unjust. If we can establish the kind of regulatory system that promotes trust and accountability between the police and their subjects, we can create the kind of discretion that makes law enforcement less unjust. Yes, we ought to be experimenting with regulating law enforcement in new ways, but no, we should not doom ourselves to the frustration and injustice of trying to stamp out police discretion in the process.

The exercise of discretion by public officers can be repressive; but once it is conceded that discretion is a product of social control, it can be seen that properly channeled discretion can also be liberating for all concerned. If discretion can produce misfortune, it can also be serendipitous. How can policing be made more serendipitous? How can the game of police discretion be turned from a zero-sum game (in which police win when offenders, and

75. Class disparity widens in the severity with which remaining offenders are punished, however. See H. Pepinsky, supra note 38 , at 85,88 .

76. See supra note 47.

77. G. Mead, Mind, Self \& Society (C. Morris ed. 1934).

78. M. Weber, The Theory of Social and Economic Organization 88-115 (T. Parsons ed. 1947). 
often victims, lose) into a mixed-sum game (in which complainants, suspects, and police win together)? It is argued here that serendipitous law enforcement rests on making police subject to regulation by the residents of the communities they patrol. Properly constructed, this game requires the police to try to exercise discretion in a way that serves the interests of those they encounter-victims and offenders alike. It lodges in community residents the primary responsibility for helping themselves to resolve their disputes short of resort to law enforcement. The game offers community members better living through creation of police discretion.

The work of Kenneth Culp Davis rests on a fallacy common to legal theory: that those who honestly follow laws, rules, and regulations behave like inanimate objects. ${ }^{79}$ Instead, if law, rules, and regulations need to be imposed, it is because human subjects need a chance to hold police accountable for their actions. Conflicting parties who use regulation have the potential of generating an infinite variety of "findings of fact" in any situation to suit their interests, as the aftermath of Miranda indicates. Indeed, one of the most highly prized skills for an American lawyer is to display ingenuity at shaping "facts" of cases to suit clients' interests. ${ }^{80}$

The greatest injustice of policing has lain not in encouraging discretion, but in all other classes arriving at a premature consensus that chronically unemployed underclass young men deserve the non-discretionary brunt of law enforcement. ${ }^{81}$ If the fundamental injustice of law enforcement gets reduced, it will entail freeing the police from undue restrictions on their management of human conflict.

79. Sociologists of law have been as guilty as lawyers of committing this fallacy. The sociology of knowledge of law and discretion would make a fascinating study in itself. I suspect that what has happened is that sociologists of law have ceded a monopoly to lawyers of knowledge of how law operates. Lawyers are presumed to be experts at using law to engineer change. If, therefore, subjects of law behave in unexpected ways, it must be that the subjects are not following law, not that lawyers misconstrue how law gets interpreted. Thus, sociologists of law assume that injustice is a failure to follow or to have law, not a product of ignorance of sociology. If only social scientists could presume themselves competent to question lawyers' myths about the rule of law, an understanding of regulations would be considerably enhanced.

80: Rich clients, obviously, tend to get a greater share of the benefits of these skills than the poor. Collectively, for instance, great skill and ingenuity have been displayed at assembling the facts to show that, by law, the rich are far less crooked than the poor.

81. See supra note 33 . 
